\title{
Self-Assessment of Career Counsellor Competences in the Field of Career Guidance Depending on the Place of Residence
}

\author{
(D) Vija Dislere ${ }^{1}$ Dr. paed.; (1) Natalja Vronska ${ }^{2}$ Dr. paed. \\ Latvia University of Life Sciences and Technologies, Latvia \\ vija.dislere@1lu.1v¹; natalja.vronska@1lu.lv²
}

\begin{abstract}
The importance of career guidance and the competences of a career counsellor is described and highlighted in this article. The counsellors are seen as key professionals assisting individuals in their educational and job transitions during their career, addressing both individual and labour market requirements. The aim of the study is to analyse the self-assessment of career counsellor competencies in the field of career guidance depending on the place of residence in Latvia. The self-evaluation of career counsellors regarding their competence was used. In the study 340 respondents took part from all Latvia regions, they were graduates of the last eleven years of the Career Counsellors Master's Program and other in-service career counsellors and school career counsellors working in schools, employment agencies and private consulting companies. The data were analysed statistically by using SPSS computer program: 1) crosstab method, 2) chi-squared test. The significance of the results and the most important conclusion: analysing the frequency of respondents' responses of excellent and good career counsellor competence depending on the place of residence, it can be concluded that excellent (Pearson Chi-Square $\mathrm{p}$-value $=0.867)$ and good (Pearson Chi-Square p-value $=0.892$ ) career counsellor competence not depending on the place of residence of the respondents, the excellent and good career counsellor competence is equally good everywhere in Latvia.
\end{abstract}

Keywords: competence, career counsellors, career guidance, career education, self-assessment.

\section{Introduction}

Nowadays, career guidance is becoming increasingly important for both for school students, for the unemployed and for workers, if the career change is needed. Career guidance is provided by career counsellors organizing events that include information on education and job opportunities, career education, and career counselling, with the aim of encouraging people in cooperation with employers, to make career decisions responsibly for choosing the education and a career path that suits their interests and abilities. To be able to do this qualitatively, career counsellors have to have appropriate competencies to provide career guidance.

A. Hirschi (2012) proposes human capital resources, social resources, psychological resources, and identity resources as critical career resources, which are essential for career development in the modern context. Human capital resources include factors such as education, experience, and cognitive ability. Social resources (called social capital) include the goodwill of individuals and availability of mentors. Psychological resources refer to psychological traits and states such as neuroticism, extraversion, conscientiousness, openness to experience, core self-evaluation, career self-efficacy, beliefs, or vocational hope. Career identity resources mean resources related to one's conscious awareness of oneself as a worker, of one's occupational interests, abilities, goals and values and of the importance of one's work. These ways of resources mutually influence each other in a dynamic process over time. All four resources can be seen as multiple component resources, each consisting of several different factors that together form the overarching resource for self-directed career management.

Such resources are necessary both for career counsellors themselves for their career development and for them to be able to support their clients in providing these resources. Career management competence can be described as an ability to act responsibly, ethically and prudently in career development situations; as well as mobilizing and combining personal and external resources to achieve desired career goals (Pavulens, 2015). One of the essential vocational services in schools is career guidance. School counsellors play a significant role in identifying psychological factors (such as career maturity, work and goal orientation, and self-efficacy) and they have an obligation to provide career orientation services to students so they can meet the challenges of the work environment and to minimize career disorientation among students that 
may damage their future careers (Suryadi et al., 2020). Career counsellor roles are as follows: facilitator of personal and professional development, consultant for those seeking a job, motivator, information supplier for labour market and occupational areas, facilitating customer access to career opportunities in the labour market, designer to initiate development activities of staff in an organization (Bobu, Soitu, 2012). The roles of a career counsellor are diverse and all their manifestations form the counsellor's competence.

With support from key stakeholders like administrators, teachers, and parents, school counsellors and school psychologists can work collaboratively to increase students' college and career readiness. For example, school counsellors and school psychologists may start by creating and implementing a needs assessment, as it relates to the developmental tasks of students (i.e., self-regulation, self-efficacy, and self-competence) that must be negotiated to ensure career readiness (Hines et al., 2019). Nowadays, there is a serious progress towards self-directed career decision-making, the task of career counsellors is to promote it to their clients.

The Certification of the Transferable Competencies Based on the Counselling Process (Stan, Suditu, Safta, 2010) means carrying out activities which should be directed both at managing the career and at personal development activities: preventing and reducing professional failure; improving psychic comfort and self-image; awareness of psychics and intellectual potential, awareness of value system; active involvement in planning their life and career; evaluation and self-evaluation of personality directed at professional orientation; acquiring the competences of communication, participation, motivation, team building and solving conflicts. Career counsellors should pay attention to the development of clients' personalities.

The concept of counsellors' career development worked out by C. Wang and J.Z. Wang (2016) includes the need for systematic training, good professional ethics, the need for improving counsellors' credibility, vocational ability, career status and professional self-identity, as well as stating the borders of work and figures out counsellors' responsibility in practical work. Many studies have been conducted to assess career-related perspectives. To prepare highly competent school counsellors, practitioners also appreciate the importance of the following training domains: guidance of learning and personal development; family counselling; occupational guidance; methods and resources for educational diagnosis; and programme design, application and evaluation (Anaya, Perez-Gonzalez, Suarez, 2011).

To ensure successful career guidance, collaboration between political structures (political need for professionalization of career guidance and counselling), structure of the labour market for career professionals (roles and functions) and the structure of the higher education system in Europe (academic cycle, degrees) is needed (Katsarov et al., 2014). Comprehensive competences of college counsellors include the capability to understand policies, the capability of perfecting knowledge structure, good verbal expression and communicative abilities, talent in a variety of entertainment and sports, and the ability to learn in pace with time (Wu, 2010). Career counsellors must be able to apply their knowledge of the structure of the labour market and to use the opportunities offered by the education system to perform their job professionally.

In order for career counsellors to be able to work qualitatively and apply their professional competencies, they need to ensure well-being in the workplace. It is important that the consultation room is warm and bright and that there are no distractions. Workplace wellness includes the following dimensions: social, occupational, spiritual, physical, intellectual, and emotional (Brizga, Peks, 2014). The study of E. Dose showed that psychological needs and satisfaction of autonomy, relatedness, and competence had a mediating effect between objective career success (financial and hierarchical) and subjective career success (social and psychological), and well-being (Dose et al., 2018). The lack of time to perform all functions attributed to the counsellor appears as a key difficulty, followed by the complexity of the students' needs and the excessive dependence on guidance teachers (López Díez-Caballero, Manzano-Soto, 2019). The main cause of job burnout of career counsellors was violation of psychological contracts. To prevent career counsellors from burning out, the boundaries of responsibility need to be clearly defined and performance measurement improved; effective and continuous training, development opportunities and emotional incentives need to be provided, it is recommended to standardize career planning (Yang, 2017).

Several studies on the competencies of on-career counsellors and school career counsellors and career guidance have already been carried out: the study on the effectivity of career guidance (Haskova, Vaculik, 
Leugnerova, 2015); the model of counselling of C.R. Ridley, D. Mollen and S.M. Kelly (2011), which include cognitive, affective, and behavioural components, the model has the integrated deep structure, which consists of 5 metacognitions: purposefulness, motivation, selection, sequencing, and timing; career counselling self-efficacy and multicultural counselling competence (Vespia et al., 2010; Mani, 2020); the study on competence-based education principles and performances applied to guidance career curriculum and in-service training programs and need to acquire strategic competences (Alvarez-Rojo, Romero-Rodriguez, 2007); competence to use the dialogue in career guidance of students (Soika, 2017); value identification methods helping career counsellors to identify career counselling boundaries as well as act professionally, ethically and wisely in assessing any particular situation (Racene, Dislere, 2019); skills for career counsellor - empathy, insight, communication and listening, flexibility and tolerance (Blank, 2017); the most frequently methods used in career counselling by L. Damberga (2013) are: clarification of values, card sorting method, SWOT analysis, interest inventory survey, case study, personal project, decision making, visualisation, life-space mapping, future visions, experience assessment, tree of life, way of life, role play, problem solving, decision making. The career counsellor must be able to apply these methods in working with the client.

The ability to use an online tool in career counselling is one of the competencies of career counsellors, what helps people in need of career guidance remotely; they can get career guidance from a career counsellor no matter when or where they are. The special competences that a career counsellor needs for using the Internet are as follows: designing a website; navigating across forums; establishing e-mail accounts and using e-mail; assisting customers in their searches for information about counselling; observing the legal acts and ethics regarding Internet counselling services; understanding the strengths and weaknesses of Internet counselling; using the Internet to identify and access continuous learning opportunities; evaluating the quality of information available on the Internet (Jigáu, 2007; Racene, Dislere, 2014).

A powerful conceptual tool to think about technology integration is the SAMR model (Terada, 2020), which lays out four tiers of online learning, presented roughly in order of their transformative power: substitution, augmentation, modification, and redefinition. Teachers often focus on the first two levels, which involve replacing traditional materials with digital ones. In classrooms where tech integration has moved to the mastery level, the last two levels of the SAMR model — modification and redefinition - should also be in the mix. Students in classes where this kind of mastery is embedded find more novel and immersive uses for technology. It's about being aware of the range of options and picking the right strategies for the lesson at hand. The study of N. Vronska showed that students make productive use of the various applications that are offered, value ICT as an instrument of permanent learning $(\mathrm{p}=0.000<0.05)$ and value ICT as a medium of collaboration and social communication $(p=0.009<0.05)$. These results suggest the need for developing strategies promoting the effective use of technology resources (Vronska, 2016). Video using helps students improve knowledge, skills, and competence in lectures, which are necessary for an individual successful study process (Vronska, 2017). That's important because in a post-coronavirus world there's likely to be a greater emphasis on digital learning including digital career counselling.

Many scientists have been working on identifying the competencies of career counsellors and exploring their needs and importance. A scientific evaluation system for counsellor's ability has been established by H. Zhu and Z. Zhou (2011), it is consistent with the needs of counsellors, and is the key to building professionalism for counsellors. The major competences of career counsellor by P. Behrani (2016) are skills of counselling, acceptance and flexibility, integrity, sensitivity, listening, empathy, confidentiality, and understanding. Competences for counselling for minorities are worked out by T. Burnes, T. Hammer (2009).

As part of the project Capacity building of the State Employment Agency, a team of experts developed standards in Quality manuals for educational and vocational counselling, which are summarized in four categories of competences: Education and Career, Counselling Practice, Personality and ICT skills covering 12 key competences: education and training, information of labour market, training skills, communication with the client, evaluation, matching the profession and getting a job, ethics, individual skills, time management, stress and frustration, development, use of ICT and information management (Karjeras konsultāciju pakalpojumu..., 2009). They are designed for self-assessment of career counsellors' work. 
The Network of Innovations in Career Guidance and Counselling in Europe (NICE) (Network for Innovations..., 2020) makes a major contribution in working out career counsellor competences. NICE is an open European network for the academic training of people who practice career guidance and counselling (career practitioners). Scientists from this network presented the fields of core competences of a career counsellor, which should be understood as fields of competence not as measurable competences (Katsarov et al., 2014): career assessment and information competence, career education competence, career systems development competence, career service management competence, career counselling competence, generic professional competence.

The following competences are required for a career counsellor to prepare the client to participate in the evaluation and validation process: to present clear and accurate information on the service to be provided, and agree on the course of action (creating the contract); to explain the client what self-evaluation is outline its benefits; to encourage the client to express his/her own personal experiences (autobiography) and assist his/her to extend what is relevant to reflect upon his/her competence; to understand and explain the evaluation scheme that the client can use to grade his/her competence; to comprehend the significance of the assessment of learning; to demonstrate intercultural awareness; to develop, maintain, and update a portfolio for assessment that reflects the overall life situation of the client and present it the best possible way; to have a good grasp of the specific methods of documentation that is required for recognition of prior learning; to understand of the requirements of and external assessor and the ability to explain the recognition process to the client; to ensure that the client has understood and gained ownership of the process (Martin, Sava, 2012).

These 10 above-mentioned competences were found the most relevant in the validation and consultation process. Client's tacit or documented real competencies are to be highlighted and compared with occupational standards and market needs. The career counsellor is expected to be able to guide the candidate to a job for such a solution for quicker certification of its competencies, for getting more chances for a better job and quicker employment.

The criteria for assessing the competence of career counsellors developed by the authors (Dislere, Vronska, 2020) have been used in this study (Table 2).

The aim of the study is to analyse the self-assessment of career counsellor competencies in the field of career guidance depending on the place of residence in Latvia.

\section{Methodology}

Research tasks:

- to analyse career counsellors' competences depending on the place of residence in Latvia;

- to discover the statistical relationship between two independent samples;

- to analyse the frequency of respondent answers and to determine statistically significant prevalence.

The study was developed at the Latvia University of Life Sciences and Technologies at the Institute of Education and Home Economics and conducted in late 2019 and early 2020. Questionnaires were sent out via email and social networks. The questionnaires were sent to graduates of the last eleven years of the Career Counsellors Master's Program and other in-service career counsellors and school career counsellors working in schools, employment agencies and private consulting companies in Latvia.

Table 1

Distribution of respondents' answers by age and place of residence (number)

\begin{tabular}{|c|c|c|c|c|c|c|}
\hline Place of residence & 20-30 & $31-40$ & $41-50$ & $51-60$ & 60 and more & Total \\
\hline Capital city & 4 & 29 & 31 & 25 & 12 & 101 \\
\hline Regions & 7 & 20 & 45 & 51 & 9 & 132 \\
\hline Republic cities & 10 & 21 & 30 & 39 & 7 & 107 \\
\hline Total & 21 & 70 & 106 & 115 & 28 & 340 \\
\hline
\end{tabular}


For the study 340 questionnaires were analysed; $6 \%$ of respondents are $20-30$ years old, $21 \%$ of respondents are $31-40$ years old, $31 \%$ of respondents are $41-50$ years old, $34 \%$ of respondents are $51-60$ years old, and $8 \%$ of respondents are 60 years old and older. Respondents' answers were split by age and place of residence: capital city, Republic city and regions of Latvia (Table 1).

Respondents were asked to fill in questionnaires and self-assess their career counsellor competencies according to the criteria developed by the authors (Table 2), where competencies were grouped into 5 fields and several sub-competences were assigned to each field. Respondents were asked what career counsellor competencies do they think they have and to what extent (3-excellent; 2-good;1-poor).

Table 2

The criteria for assessing the competence of career counsellors (Dislere, Vronska, 2020)

\begin{tabular}{|c|c|c|}
\hline $\mathbf{N}$ & $\begin{array}{c}\text { Criteria field of } \\
\text { competence }\end{array}$ & Sub-competences \\
\hline 1 & $\begin{array}{l}\text { Career } \\
\text { information } \\
\text { competence }\end{array}$ & $\begin{array}{l}\text { - knowledge of updated information on educational and training } \\
\text { - knowledge of updated information on employment trends, labour market, and } \\
\text { social issues }\end{array}$ \\
\hline 2 & $\begin{array}{l}\text { Career } \\
\text { education } \\
\text { competence }\end{array}$ & $\begin{array}{l}\text { - to integrate the theory and research into practice in guidance } \\
\text { - to demonstrate the knowledge of the lifelong career development process } \\
\text { - to use the goal setting task in training } \\
\text { - to use career planning and decision making in training }\end{array}$ \\
\hline 3 & $\begin{array}{l}\text { Career } \\
\text { counselling } \\
\text { competence }\end{array}$ & $\begin{array}{l}\text { - exploration competency } \\
\text { - selection and using of diagnostic methods } \\
\text { - use of counselling methods } \\
\text { - to be able to interact with a client in individual counselling } \\
\text { - to be able to interact with a client in group counselling } \\
\text { - ability to use of dialogue in career guidance } \\
\text { - a multicultural career counselling }\end{array}$ \\
\hline 4 & $\begin{array}{l}\text { Career service } \\
\text { managing } \\
\text { competence }\end{array}$ & $\begin{array}{l}\text { - ability to implement a variety of career support models and programmes } \\
\text { - ability to carry out a variety of career support models and programmes } \\
\text { - skills to cooperate effectively in a team of professionals, } \\
\text { - knowledge of (office) politics } \\
\text { - networking ability }\end{array}$ \\
\hline 5 & $\begin{array}{l}\text { Generic } \\
\text { competence }\end{array}$ & $\begin{array}{l}\text { - empathy, insight } \\
\text { - communication and listening, } \\
\text { - flexibility and tolerance } \\
\text { - observing ethical standards } \\
\text { - awareness and appreciation of clients' cultural differences, } \\
\text { - use online tools in career counselling } \\
\text { - workplace wellness } \\
\text { - awareness of own capacity }\end{array}$ \\
\hline
\end{tabular}

Research methods:

- data collection methods: questionnaire;

- data processing methods:

- crosstab method (McCormick, Salcedo, 2017);

- chi-square test (Gunarto, 2019).

The data were analysed statistically by using SPSS software.

\section{Results and Discussion}

The frequency of respondent answers was analysed using crosstabs, which summarize the relationship between different variables of categorical data (excellent career counsellor competencies, good career counsellor competencies and need to improve career counsellor competencies). Crosstabs were analysed below and showed the proportion of cases in subgroups (Tables 3 -8). Table 3 shows the excellent competencies of a career counsellor depending on the place of residence in Latvia: capital city, Republic cities or regions of Latvia. 
Excellent career counsellor competencies depending on the place of residence

\begin{tabular}{|c|c|c|c|c|c|c|c|}
\hline \multicolumn{2}{|c|}{ Place of residence } & \multirow{2}{*}{ 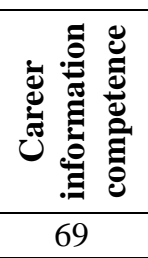 } & \multirow{2}{*}{ 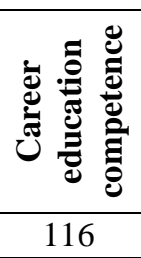 } & \multirow{2}{*}{ 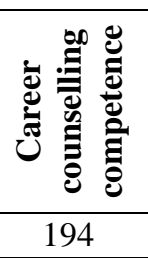 } & \multirow{2}{*}{ 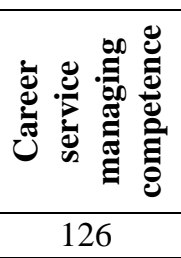 } & \multirow{2}{*}{ 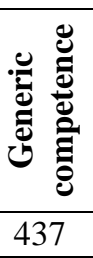 } & \multirow{2}{*}{$\begin{array}{l}\text { Total } \\
942 \\
\end{array}$} \\
\hline \multirow{2}{*}{$\begin{array}{l}\text { Capital } \\
\text { city }\end{array}$} & Frequency of answers & & & & & & \\
\hline & $\%$ of Total & 2.2 & 3.6 & 6.1 & 3.9 & 13.6 & 29.4 \\
\hline \multirow{2}{*}{$\begin{array}{l}\text { Republic } \\
\text { cities }\end{array}$} & Frequency of answers & 85 & 145 & 223 & 150 & 512 & 1115 \\
\hline & $\%$ of Total & 2.7 & 4.5 & 7.0 & 4.7 & 16.0 & 34.8 \\
\hline \multirow{2}{*}{ Regions } & Frequency of answers & 88 & 129 & 229 & 140 & 563 & 1149 \\
\hline & $\%$ of Total & 2.7 & 4.0 & 7.1 & 4.4 & 17.6 & 35.8 \\
\hline \multirow{2}{*}{ Total } & Frequency of answers & 242 & 390 & 646 & 416 & 1512 & 3206 \\
\hline & $\%$ of Total & 7.5 & 12.2 & 20.1 & 13.0 & 47.2 & 100.0 \\
\hline
\end{tabular}

The crosstabs results were interpreted in percentages: career counsellors with excellent generic competence from the capital city make up $13.6 \%$ of the sample, from Republic cities make up $16.0 \%$ of the sample, and from regions make up $17.6 \%$ of the sample. Career counsellors with excellent career service managing competence from the capital city make up $3.9 \%$ of the sample, from Republic cities make up $4.7 \%$ of the sample, and from regions make up $4.4 \%$ of the sample. Career counsellors with excellent career counselling competence from the capital city make up $6.1 \%$ of the sample, from Republic cities make up $7.0 \%$ of the sample, and from regions make up $7.1 \%$ of the sample. Career counsellors with excellent career education competence from the capital city make up $3.6 \%$ of the sample, from Republic cities make up $4.5 \%$ of the sample, and from regions make up $4.0 \%$ of the sample. Career counsellors with excellent career information competence from the capital city make up $2.2 \%$ of the sample, from Republic cities make up $2.7 \%$ of the sample, and from regions make up $2.7 \%$ of the sample.

The following hypotheses were tested for further data analysis:

- null hypothesis: the association between the place of residence and self-assessment of competencies is not statistically significant;

- alternative hypothesis: there is a statistically significant association between the place of residence and self-assessment of competencies.

The Pearson Chi-Square p-value $=0.867$ (Table 4), so the null hypothesis is not rejected. It means excellent career counsellor competence not depending on the place of residence (capital city, Republic cities or regions) in Latvia.

Table 4

Crosstabs Chi-Square test of excellent career counsellor competence

\begin{tabular}{|l|c|c|c|}
\hline \multicolumn{1}{|c|}{ Crosstabs Chi-Square test indicators } & Value & df & $\begin{array}{c}\text { Asymptotic Significance } \\
\text { (2-sided) }\end{array}$ \\
\hline Pearson Chi-Square & 3.888 & 8 & $\mathbf{0 . 8 6 7}$ \\
\hline Likelihood Ratio & 3.897 & 8 & 0.866 \\
\hline N of Valid Cases & 3206 & & \\
\hline
\end{tabular}

Table 5 shows the good competence of a career counsellor depending on the place of residence in Latvia: capital city, Republic cities or regions of Latvia. The crosstabs results were interpreted in percentages: career counsellors with good generic competence from the capital city make up $7.4 \%$ of the sample, from Republic cities make up $7.0 \%$ of the sample, and from regions make up $10.2 \%$ of the sample. Career counsellors with good career service managing competence from the capital city make up $6.1 \%$ of the sample, from Republic cities make up $6.4 \%$ of the sample, and from regions make up $8.9 \%$ of the sample. Career counsellors with good career counselling competence from capital city make up $7.7 \%$ of the sample, from Republic cities make up $8.6 \%$ of the sample, and from regions make up $11.7 \%$ of the sample. Career counsellors with good career education competence from the capital city make up $5.2 \%$ of the sample, from Republic cities make up $5.0 \%$ of the sample, and from regions make up $7.4 \%$ of the sample. Career counsellors with good career information competence from the capital 
city make up $2.5 \%$ of the sample, from Republic cities make up $2.6 \%$ of the sample, and from regions make up $3.5 \%$ of the sample.

Table 5

Good career counsellor competence depending on the place of residence

\begin{tabular}{|c|c|c|c|c|c|c|c|}
\hline \multicolumn{2}{|c|}{ Place } & \multirow{2}{*}{ 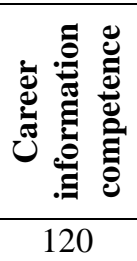 } & \multirow{2}{*}{ 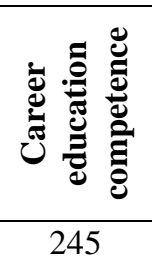 } & \multirow{2}{*}{ 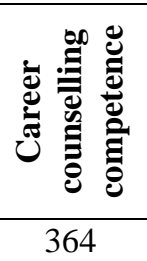 } & \multirow{2}{*}{ 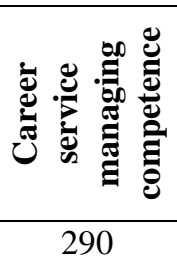 } & \multirow{2}{*}{ 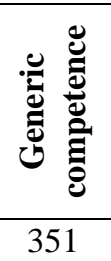 } & \multirow{2}{*}{$\begin{array}{l}\text { Total } \\
1370 \\
\end{array}$} \\
\hline \multirow{2}{*}{$\begin{array}{l}\text { Capital } \\
\text { city }\end{array}$} & Frequenc & & & & & & \\
\hline & $\%$ of Total & 2.5 & 5.2 & 7.7 & 6.1 & 7.4 & 29.0 \\
\hline \multirow{2}{*}{$\begin{array}{l}\text { Republic } \\
\text { cities }\end{array}$} & Frequency of & 121 & 236 & 407 & 302 & 329 & 1395 \\
\hline & $\%$ of Total & 2.6 & 5.0 & 8.6 & 6.4 & 7.0 & 29.5 \\
\hline \multirow{2}{*}{ Regions } & Frequency of answers & 164 & 349 & 552 & 420 & 481 & 1966 \\
\hline & $\%$ of Total & 3.5 & 7.4 & 11.7 & 8.9 & 10.2 & 41.6 \\
\hline \multirow{2}{*}{ Total } & Frequency of answers & 405 & 830 & 1323 & 1012 & 1161 & 4731 \\
\hline & $\%$ of Total & 8.6 & 17.5 & 28.0 & 21.4 & 24.5 & 100.0 \\
\hline
\end{tabular}

The following hypotheses were tested for further data analysis:

- null hypothesis: the association between the place of residence and self-assessment of competencies is not statistically significant;

- alternative hypothesis: there is a statistically significant association between the place of residence and self-assessment of competencies.

The Pearson Chi-Square p-value $=0.892$ (Table 6), so the null hypothesis is not rejected. It means good career counsellor competence not depending on the place of residence (capital city, Republic cities or regions) in Latvia.

Table 6

Crosstabs Chi-Square test of good career counsellor competence

\begin{tabular}{|l|c|c|c|}
\hline \multicolumn{1}{|c|}{ Crosstabs Chi-Square test indicators } & Value & df & $\begin{array}{c}\text { Asymptotic Significance } \\
\text { (2-sided) }\end{array}$ \\
\hline Pearson Chi-Square & 3.590 & 8 & $\mathbf{0 . 8 9 2}$ \\
\hline Likelihood Ratio & 3.596 & 8 & 0.892 \\
\hline N of Valid Cases & 4731 & & \\
\hline
\end{tabular}

Table 7 shows the need to improve the competence of a career counsellor depending on the place of residence in Latvia: capital city, Republic cities or regions of Latvia.

Table 7

The need to improve career counsellor competence depending on the place of residence

\begin{tabular}{|c|c|c|c|c|c|c|c|}
\hline & ace of residence & 造 & 总 & 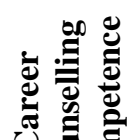 & 离 & 怤 & Total \\
\hline Capital & Frequency of answers & 11 & 36 & 124 & 80 & 11 & 262 \\
\hline & $\%$ of Total & 1.5 & 5.1 & 17.5 & 11.3 & 1.5 & 36.9 \\
\hline Republic & Frequency of answers & 7 & 45 & 11 & 77 & 14 & 154 \\
\hline cities & $\%$ of Total & 1.0 & 6.3 & 1.5 & 10.8 & 2.0 & 21.7 \\
\hline Perions & Frequency of answers & 12 & 49 & 128 & 97 & 8 & 294 \\
\hline Kegions & $\%$ of Total & 1.7 & 6.9 & 18.0 & 13.7 & 1.1 & 41.4 \\
\hline & Frequency of answers & 30 & 130 & 263 & 254 & 33 & 710 \\
\hline Total & $\%$ of Total & 4.2 & 18.3 & 37.0 & 35.8 & 4.6 & 100.0 \\
\hline
\end{tabular}


The crosstabs results were interpreted in percentages: career counsellors who need to improve generic competence from the capital city make up $1.5 \%$ of the sample, from Republic cities make up $2.0 \%$ of the sample, and from regions make up $1.1 \%$ of the sample. Career counsellors who need to improve career service managing competence from the capital city make up $11.3 \%$ of the sample, from Republic cities make up $10.8 \%$ of the sample, and from regions make up $13.7 \%$ of the sample. Career counsellors who need to improve career counselling competence from the capital city make up $17.5 \%$ of the sample, from Republic cities make up $1.5 \%$ of the sample, and from regions make up $18.0 \%$ of the sample. Career counsellors who need to improve career education competence from the capital city make up $5.1 \%$ of the sample, from Republic cities make up $6.3 \%$ of the sample, and from regions make up $6.9 \%$ of the sample. Career counsellors who need to improve career information competence from the capital city make up $1.5 \%$ of the sample, from Republic cities make up $1.0 \%$ of the sample, and from regions make up $1.7 \%$ of the sample.

The following hypotheses were tested for further data analysis:

- null hypothesis: the association between the place of residence and self-assessment of competencies is not statistically significant;

- alternative hypothesis: there is a statistically significant association between the place of residence and self-assessment of competencies.

The Pearson Chi-Square p-value $=0.000$ (Table 8), so the null hypothesis must be rejected and the alternative hypothesis accepted. It means that the need to improve career counsellor competence is depending on the place of residence (capital city, Republic cities or regions) in Latvia.

Table 8

Crosstabs Chi-Square test of the need to improve career counsellor competence

\begin{tabular}{|l|c|c|c|}
\hline Crosstabs Chi-Square test indicators & Value & df & $\begin{array}{c}\text { Asymptotic Significance } \\
\text { (2-sided) }\end{array}$ \\
\hline Pearson Chi-Square & 81.845 & 8 & $\mathbf{0 . 0 0 0}$ \\
\hline Likelihood Ratio & 96.650 & 8 & 0.000 \\
\hline N of Valid Cases & 710 & & \\
\hline
\end{tabular}

The frequency of respondent answers (the need to improve career counsellor competence) was statistically analysed using chi-square test (Tables 9-11).

The following hypotheses were tested for further data analysis:

- null hypothesis: the frequency of the answers is about the same in all places of residence;

- alternative hypothesis: the frequency of respondent answers differs significantly.

The frequency of capital city's respondent answers was statistically analysed in Table 9.

Table 9

Chi-square test statistics of capital city's respondents

\begin{tabular}{|l|c|c|c|}
\hline \multicolumn{1}{|c|}{ Criteria } & Observed N & Expected N & Residual \\
\hline Career information competence & 11 & 52.4 & -41.4 \\
\hline Career education competence & 36 & 52.4 & -16.4 \\
\hline Career counselling competence & 124 & 52.4 & 71.6 \\
\hline Career service managing competence & 80 & 52.4 & 27.6 \\
\hline Generic competence & 11 & 52.4 & -41.4 \\
\hline Chi-Square & \multicolumn{3}{|c|}{182.924} \\
\hline df & 4 & 0.000 \\
\hline Asymp. Sig. & \multicolumn{3}{|c|}{} \\
\hline
\end{tabular}

Since the p-value $=0.000$ is less than the significance level of $\alpha=0.05$, the null hypothesis can be rejected. Thus, it can be concluded that the frequency of respondent answers is different. Statistically significant prevalence was the answer Career counselling competence (71.6). This means that capital city's respondents need to improve career counselling competence.

The frequency of Republic city's respondent answers was statistically analysed in Table 10. 
Chi-square test statistics of Republic city's respondents

\begin{tabular}{|l|c|c|c|}
\hline \multicolumn{1}{|c|}{ Criteria } & Observed N & Expected N & Residual \\
\hline Career information competence & 7 & 30.8 & -23.8 \\
\hline Career education competence & 45 & 30.8 & 14.2 \\
\hline Career counselling competence & 11 & 30.8 & -19.8 \\
\hline Career service managing competence & 77 & 30.8 & 46.2 \\
\hline Generic competence & 14 & 30.8 & -16.8 \\
\hline Chi-Square & \multicolumn{3}{|c|}{116.130} \\
\hline df & 4 \\
\hline Asymp. Sig. & 0.000 \\
\hline
\end{tabular}

Since the p-value $=0.000$ is less than the significance level of $\alpha=0.05$, the null hypothesis can be rejected. Thus, it can be concluded that the frequency of respondent answers is different. Statistically significant prevalence was the answer Career service managing competence (46.2). This means that Republic city's respondents need to improve career service managing competence.

The frequency of region's respondent answers was statistically analysed in Table 11.

Table 11

\section{Chi-square test statistics of region's respondents}

\begin{tabular}{|l|c|c|c|}
\hline \multicolumn{1}{|c|}{ Criteria } & Observed N & Expected N & Residual \\
\hline Career information competence & 12 & 58.8 & -46.8 \\
\hline Career education competence & 49 & 58.8 & -9.8 \\
\hline Career counselling competence & 128 & 58.8 & 69.2 \\
\hline Career service managing competence & 97 & 58.8 & 38.2 \\
\hline Generic competences & 8 & 58.8 & -50.8 \\
\hline Chi-Square & \multicolumn{3}{|c|}{187.027} \\
\hline df & \multicolumn{3}{|c}{0.000} \\
\hline Asymp. Sig. & \multicolumn{3}{|c}{} \\
\hline
\end{tabular}

Since the p-value $=0.000$ is less than the significance level of $\alpha=0.05$, the null hypothesis can be rejected. Thus, it can be concluded that the frequency of respondent answers is different. Statistically significant prevalence was the answer Career counselling competence (69.2). This means that region's respondents need to improve career counselling competence.

\section{Conclusions}

Career counsellors provide career counselling through both informative and educational activities, combined with individual or group counselling, with the aim to encourage clients to make responsible and balanced career decisions in cooperation with employers, choosing an education and career path that suits their true interests, talents and capabilities. Nowadays, there is a serious progress towards selfdirected career decision-making, the task of career counsellors is to promote it to their clients. The career counsellor has to demonstrate own professional credibility, vocational ability, career status and professional self-identity, as well as stating the borders of work and responsibilities, what would be helpful for the clients in choosing a career counsellor. Important career counsellor competencies are counselling, acceptance and flexibility, integrity, sensitivity, listening, empathy, understanding, confidentiality and use of ICT and information management skills. The authors acknowledge the following as the most important competencies of a career counsellor: career information competence, career education competence, career counselling competence, career service competence and generic competence, which were evaluated and the results of the research are as follows.

Analysing the frequency of respondents' responses of excellent and good career counsellor competence depending on the place of residence, it can be concluded that excellent (Pearson Chi-Square p-value $=$ 0.867 ) and good (Pearson Chi-Square p-value $=0.892$ ) career counsellor competence not depending on 
the place of residence (capital city, Republic cities or regions) in Latvia. This means that excellent and good career counsellor competence is equally good everywhere in Latvia.

However, analysing the frequency of respondents' responses of the need to improve career counsellor competence depending on the place of residence, it can be concluded that the frequency of respondents' responses is different in the capital city, Republic cities or region (Pearson Chi-Square p-value $=0.000$ ).

Analysing the differences in frequencies of respondents' responses using the chi-square test, it can be concluded that both respondents of the capital city $(\mathrm{p}$-value $=0.000<0.05$, residual $=71.6)$ and respondents of regions ( $\mathrm{p}$-value $=0.000<0.05$, residual $=69.2$ ) need to improve career counselling competence. However, respondents of Republic cities ( $\mathrm{p}$-value $=0.000<0.05$, residual $=46.2$ ) need to improve career service managing competence.

\section{Bibliography}

1. Alvarez-Rojo V., Romero-Rodriguez S. (2007). Formacion basada en competencias para los profesionāles de la orientacion (Competence-based Education and Training for Guidance Professionals). Education XX1(10), 15-37. doi: 10.5944/educxx1.1.10.295 (in Rumanian)

2. Anaya D., Perez-Gonzalez J.C., Suarez J.M. (2011). Los contenidos de formación de los profesionales de la orientación educativa desde la perspectiva de los propios orientadores (School Counselor's Training Domains from the Practitioners' Point of View). Revista de Educación, 356, 607-629. Retrieved from http://www.revistaeducacion.educacion.es/re356/re356_25.pdf (in Rumanian)

3. Behrani P. (2016). Importance of Teaching Counselling Skills to Teachers. MIER Journal of Educational Studies, Trends and Practices, 6(1), 17-25. Retrieved from http://kslreview.org/index.php/mjestp/article/download/1452/1077

4. Blank C. (2017). Skills for a Career Counselor. Chron. Retrieved from https://work.chron.com/skills-career-counselor-1077.html

5. Bobu R., Soitu L. (2012). Competences and roles of career counsellors. In G.K. Zarifis, K. Martin., S. Sava (Eds.), International conference Back to Work - The Role of Validation of Competences in Professional Counselling of Adults. Thessaloniki, Greece: MEDIMOND, 1-4. Retrieved from https://www.academia.edu/2364861/Back_to_Work-

The_Role_of_Validation_of_Competences_in_Professional_Counseling_of_Adults

6. Brizga D., Peks L. (2014). Workplace wellness and specialists' attitude to work safety. In V. Dislere (Ed.), The Proceedings of the International Scientific Conference Rural Environment. Education. Personality (REEP), 7. Jelgava: LLU, 90-96. Retrieved from:

https://llufb.llu.lv/conference/REEP/2014/Latvia-Univ-Agricult-REEP-2014proceedings-90-96.pdf

7. Burnes T., Hammer T. (Eds.). (2009). ALGBTIC Competencies for Counseling LGBQIQA. Competencies for Counselling. Retrieved from https://www.counseling.org/docs/defaultsource/competencies/algbtic-competencies-for-counseling-lgbqiqa.pdf?sfvrsn=1c9c89e_14

8. Damberga L. (2013). Usage of Career Counselling Methods. In V. Dislere (Ed.), The Proceedings of the International Scientific Conference Rural Environment. Education. Personality (REEP), 6. Jelgava: LLU, 118-125. Retrieved from: https://llufb.llu.lv/conference/REEP/2013/Latvia-UnivAgricult_REEP_2013_ISSN_2255-808X-118-125.pdf

9. Dislere V., Vronska N. (2020). Evaluation of Career Counsellors' Competences in Career Guidance. In V. Dislere (Ed.), The Proceedings of the International Scientific Conference Rural Environment. Education. Personality (REEP), 13. Jelgava: Latvia University of Life Sciences and Technologies, 385-399. doi: 10.22616/REEP.2020.046

10. Dose E., Desrumaux P., Sovet L., De Bosscher S. (2018). Succès de carrière et bien-être psychologique au travail des conseiller-e-s de l'accompagnement professionnel: rôle médiateur de la satisfaction des besoins psychologiques (Career Success and Psychological Well-being at Work of Career Counselors: Mediating Role of Psychological Needs Satisfaction). Psychologie du Travail et des Organisations, 24(1), 86-107. doi: 10.1016/j.pto.2017.05.002 (in France)

11. Gunarto H. (2019). Parametric and Nonparametric Data Analysis for Social Research: IBM SPSS. Mauritius, LAP Lambert Academic Publishing.

12. Haskova K., Vaculik M., Leugnerova M. (2015). Efektivita kariérového poradenství (Effectivity of Career Guidance). In M. Rymeš, I. Gillernová (Eds), The Conference Psychologie Prace 
a Organizace. Praha: Czech Republic, 103-109. Retrieved from https://kpskonference.ff.cuni.cz/wpcontent/uploads/sites/87/2016/01/Psychologie-prace-2015-text.pdf\#page=103 (in Czech)

13. Hines E.M., Vega D.D., Mayes R., Harris P.C., Mack M. (2019). School counsellors and school psychologists as collaborators of college and career readiness for students in urban school settings. Journal for Multicultural Education, 13(3), 190-202. doi: 10.1108/JME-02-2019-0015

14. Hirschi A. (2012). The Career Resources Model: an Integrative Framework for Career Counsellors. British Journal of Guidance and Counselling, 40(4), 369-383. doi: 10.1080/03069885.2012.700506

15. Jigáu M. (Ed.). (2007). Career Counselling, Compendium of Methods and Techniques. Bucharest: AFIR. Retrieved from https://fliphtml5.com/lnym/leub/basic

16. Karjeras konsultāciju pakalpojumu etalonmērījums (Bench-marking) [Benchmarking of career counseling services]. (2009). Rīga: SIA Projektu un kvalitātes vadība. (in Latvian)

17. Katsarov J., Lerkkanen J., Pouyaud J., Pukelis K. (2014). Coming to European Competence Standards for the Practice of Career Guidance and Counselling. Canterbury, UK: NICE. doi: 10.11588/nicenl.2014.0.16721

18. López Díez-Caballero M.E., Manzano-Soto N. (2019). Valoración del nuevo modelo de orientación implementado en la comunidad autónoma de Cantabria por parte de los orientadores educativos (Evaluation of the New Counselling Model Carried out in Cantabria by Guidance Teachers). Revista Espanola de Orientacion y Psicopedagogia, 30(2), 108-127.

doi: 10.5944/reop.vol.30.num.2.2019.25341 (in Spanish)

19. Mani P.S. (2020). Career Self-Management and Development of Multicultural Knowledge and Practice: Experience of Professional Counsellors. Canadian Journal of Family and Youth, 12(1), 124- 146. doi: 10.29173/cjfy29494

20. Martin C., Sava S. (2012). Competences of Career Counsellor for Preparing the Validation of Competence. In G.K. Zafirs, C. Martin, S. Sava (Eds.), Back to Work - The Role of Validation of Competencies in Professional Counseling of Adults. Bologna: Italy, 53-58. Retrieved from https://www.slideshare.net/FolkuniversitetetUppsala/igma-article-1-final

21. McCormick K., Salcedo J. (2017). SPSS Statistics for Data Analysis and Visualization. Indianapolis, John Wiley and Sons, 528.

22. Network for Innovations in Career Guidance and Counselling in Europe (NICE). (2020). Retrieved from http://www.nice-network.eu/

23. Pavulens J. (2015). Career Management: Towards Constructivist Model. In V. Dislere (Ed.), The Proceedings of the International Scientific Conference Rural Environment. Education. Personality (REEP), 8. Jelgava: LLU, 329-337. Retrieved from: https://llufb.llu.lv/conference/REEP/2015/Latvia-Univ-Agricult-REEP-2015proceedings-329-337.pdf

24. Racene A., Dislere V. (2014). Internet tools as a kind of career e-guidance. In V. Dislere (Ed.), The Proceedings of the International Scientific Conference Rural Environment. Education. Personality (REEP), 7. Jelgava: LLU, 200-207. Retrieved from https://llufb.llu.lv/conference/REEP/2014/Latvia-Univ-Agricult-REEP-2014proceedings-200-207.pdf

25. Racene A., Dislere V. (2019). Choice of a Value Identification Method in Career Counselling. In V. Dislere (Ed.), The Proceedings of the International Scientific Conference Rural Environment. Education. Personality (REEP), 12. Jelgava: Latvia University of Life Sciences and Technologies, 289-296. doi: 10.22616/REEP.2019.038

26. Ridley C.R., Mollen D., Kelly S.M. (2011). Beyond Microskills: Toward a Model of Counseling Competence. The Counseling Psychologist, 39(6), 793-799. doi: 10.1177/0011000010378440

27. Soika I. (2017). Evolution of Dialogue for Students' Career Guidance in Secondary Vocational Education. In V. Dislere (Ed.), The Proceedings of the International Scientific Conference Rural Environment. Education. Personality (REEP), 10. Jelgava: LLU, 481-488. Retrieved from https://llufb.llu.lv/conference/REEP/2017/Latvia-Univ-Agricult-REEP-2017_proceedings-481-488.pdf

28. Stan E., Suditu M., Safta C.G. (2010). The Certification of the Transferable Competencies Based on the Counseling Process The Romania case study. Procedia Social and Behavioral Sciences, 5, 2020-2026. doi: 10.1016/j.sbspro.2010.07.407

29. Suryadi B., Sawitri D.R., Hayat B., Putra M.D.K. (2020). The Influence of Adolescent-Parent Career Congruence and Counselor Roles in Vocational Guidance on the Career Orientation of Students. International Journal of Instruction, 13(2), 45-60. doi: 10.29333/iji.2020.1324a 
30. Terada Y. (2020). A Powerful Model for Understanding Good Tech Integration. Retrieved from https://www.edutopia.org/article/powerful-model-understanding-good-tech-integration

31. Vespia K.M., Fitzpatrik M.E., Fouad N.A., Kantamneni N., Chen Y.L. (2010). Multicultural Career Counseling: A National Survey of Competencies and Practices. Career Development Quarterly, 59(1), 54-71. doi: 10.1002/j.2161-0045.2010.tb00130.x

32. Vronska N. (2016). ICT Competences as a Necessary Part of Professional Qualities at the Latvia University of Agriculture. In V. Dislere (Ed.), The Proceedings of the International Scientific Conference Rural Environment. Education. Personality (REEP), 9. Jelgava: LLU, 122-127. Retrieved from https://llufb.llu.1v/conference/REEP/2016/Latvia-Univ-Agricult-REEP-2016proceed2255808X-122-127.pdf

33. Vronska N. (2017). Use of Videos to Support Teaching and Learning in the Study Process. In V. Dislere (Ed.), The Proceedings of the International Scientific Conference Rural Environment. Education. Personality (REEP), 10. Jelgava: LLU, 321-327. Retrieved from https://llufb.llu.lv/conference/REEP/2017/Latvia-Univ-Agricult-REEP-2017_proceedings-321-327.pdf

34. Wang C., Wang J.Z. (2016). The Research on the Problems and Countermeasures of College Counselors' Career Development. In Z. Wang, C. Guiran, Z. Huiyu (Eds.), The Proceedings of the International Conference on Mechatronics, Computer and Education Informationization (MCEI 2016), 6, 290-294. doi: 10.2991/mcei-16.2016.61

35. Wu X.X. (2010). Study of Development of Comprehensive Competence of College Counsellors in the New Situation. In J.K. Hung, P.B. Zhao, L. Zhenmin (Eds.), Proceedings of the International Conference on Education Management Science and Engineering, 3. YanAn, China, 959-963.

36. Yang X. (2017). Cause Analysis and Coping Approaches towards Job Burnout of College Counselors Based on Psychological Contract Theory. In the International Conference on Education and Social Development (ICESD), 3. Hian, China: DEStech Publications. Retrieved from http://dpiproceedings.com/index.php/dtssehs/article/download/11714/11255

37. Zhu H., Zhou Z. (2011). The research on the Universities Counselor's Profession and Competence. In Z.H. Xu, G. Shen, S. Lin (Eds.), Achievements in Engineering Materials, Energy, Management and Control Based on Information Technology, Part1 and 2, 171-172, Beijing, China, 752-755. doi: 10.4028/www.scientific.net/AMR.171-172.752 